\title{
Effect of Column Spacing on Economy of G+5 R.C Moment Resisting Frame - A Typical Computer Aided Case Study
}

\author{
Markandeya Raju Ponnada \\ Professor and Head, Department of Civil Engineering, \\ MVGR College of Engineering, \\ Chintalavalasa, VIZIANAGARAM, PIN 535005, A.P, INDIA. \\ Mobile: +91 9440528403, markandeyaraju@gmail.com
}

\begin{abstract}
The economy of a multistory building depends on the spacing of columns which in turn depends on panel size of slab. The objective of this work is to design an economical G+5 building by finding the optimum spacing of columns. This work is limited to plot area of $30 \mathrm{mX} 30 \mathrm{~m}$ (with Aspect ratio of Panel varied from 1 to 4) for first case and in second case they were $30 \mathrm{~m} \times 30 \mathrm{~m}, 30 \mathrm{mX} 24 \mathrm{~m}, 30 \mathrm{mX} 18 \mathrm{~m}$ and $30 \mathrm{mX} 12 \mathrm{~m}$ (with Aspect ratio of sites varied from 1, 0.8, 0.6 and 0.4 respectively). In case two each plot area is again divided into panels of different aspect ratios. Here, Aspect ratio is ratio of longer dimension to shorter dimension of panel. The structure is modeled, analysed and designed as per IS : 456 - 2000 using Staad.Pro. Failed members are re-designed till all members are safe. This procedure is repeated for all cases and the quantities of steel and concrete are noted. It was observed that for $30 \mathrm{~m} \times 30 \mathrm{~m}$ plot area for aspect ratio $=1$, in Case 1Case 41 with 25 columns and in Case 2-Case 31 with 12 columns were observed to be the most economical. In these two cases, Case-1 is more economical. In Case 1, Square module $30 \mathrm{mX} 30 \mathrm{~m}$ with spacing of columns at $5 \mathrm{~m}$ and 25 panels in both sides was found to be cost effective. In Case-2 rectangular module $30 \mathrm{mX} 24 \mathrm{~m}$ for aspect ratio 0.8 with spacing of columns $15 \mathrm{mX} 12 \mathrm{~m}$ and 4 panels in both sides was found to be cost effective. For rectangular module $30 \mathrm{~m} \times 18 \mathrm{~m}$ for aspect ratio 0.6 with spacing of columns $15 \mathrm{mX} 6 \mathrm{~m}$ and 6 panels in both sides was found to be cost effective. For rectangular module $30 \mathrm{mX} 12 \mathrm{~m}$ for aspect ratio 0.4 with spacing of columns $15 \mathrm{mX} 6 \mathrm{~m}$ and 4 panels in both sides was found to be cost effective.
\end{abstract}

Keywords: multistory building, Optimum column spacing, aspect ratio, plot area, panel size, Staad.Pro, re-design, concrete and steel quantity

\section{Introduction}

With increased population and land requirement for residential and commercial purposes in urban areas, multistoried buildings are becoming common in construction industry. When compared to low-rise buildings, apartments and multistory buildings accommodate more people per unit of area of land and also decrease the cost per unit area of the construction. The quantity of steel and concrete requirement for footings, beams, columns and slabs contribute mostly to the overall cost of the structure. Further these quantities are variable while cost of finishing's and building services is constant for a constant built up area. Hence, in the economy point of view, it is important to reduce the quantities of both steel and concrete without compromising on quality and design requirements.

The total quantity of steel and concrete requirement depends on the spacing's of columns which is the panel size of the slab. If the spacing of columns is more, the number of columns is less and hence 


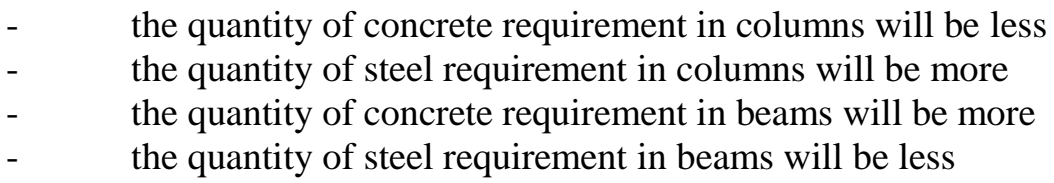

Hence, as spacing of columns increases, bending moments increase and ultimately design may become uneconomical.

If the spacing of columns is less, number of columns is more and hence the quantity of concrete requirement in columns will be more the quantity of steel requirement in columns will be less the quantity of concrete requirement in beams will be less the quantity of steel requirement in beams will be more

Hence, reduced spacing of columns may also lead to uneconomical design.

Therefore, if in a multistory building, column positioning is not a constraint, then it is advisable to arrive at optimum spacing of columns that results in minimum quantities of steel and concrete requirement for a given built up area and hence economical design. In some countries, concrete would be very costly while in others, steel. Perhaps the best option here would be an interactive, trial and error approach using good software, and the governing minimum quantities.

The optimal spacing of columns in a building generally depends on some of the following factors.

1) Scale of economics in project. For small projects, even if \% saving is high, net saving is less.

2) Bearing capacity of soil as close proximity of columns end up in designing combined strip footings which is obviously not cost effective compared to isolated footings.

3) Column height which affects buckling and bending moments derived from the horizontal loads.

4) Material of construction. If it is steel structure the spacing is determined by steel sections like girders, channel sections or angles and impact of live load has to be considered. Structural engineer likes closer columns to give economical floor plate (with or without beams). However, foundations are not cost effective with closer columns. It is variable by SBC.

5) Required stiffness (1/150 to $1 / 1000 \ldots)$ in the earthquake resistance requirement point of view.

6) Limitations on height, size and number of floors based on local building bye laws

7) Function / usage of the building space i.e. if it is a carpark then the gap between 3 car bay spaces ( $3 \mathrm{~m}$ to $8 \mathrm{~m}$ ) dictates the spacing of columns, if it is a concrete deck, it is different.

8) Economic span/depth ratios of the supporting beams in limiting deflections. Generally $6 \mathrm{~m}$ to $9 \mathrm{~m}$ practical span of beams and thus column spacing's are adopted.

9) Cost and user's convenience via-a-vis architect's planning. The architect would like large spans and hence will place columns more for aesthetic values rather than economics.

The economy from a builder's point of view is, more the number of car parks, more the earning compared to saving by reducing the spacing of columns. Service engineer, Likes larger open spaces and very thin floor plate to accommodate services and less floor volume for energy efficiency. Contractor wants simple structure without 
cantilevers, transfer girders. Hence, to determine the true and optimum values of column spacing is more a research problem of mathematics and not engineering alone. The objective of this work is to arrive at the optimum spacing of columns assuming that the above factors do not interfere with the spacing of columns.

\section{Literature Review}

Vyas and Raisinghani, 2007 [1] conducted a study on Optimum spacing of Columns based on Cost of Construction in Laboratory Buildings. Several engineering laboratory modules for technical institutions have been investigated with respect to structural cost per unit floor area. The module with a spacing of columns at $6 \mathrm{~m}(20 \mathrm{ft})$ centre distance along length was found to be cost effective for laboratory blocks up to two storey's and columns with $4.27 \mathrm{~m}$ centre distance along length are cost effective for laboratory blocks more than two storey's high. Detailed cost analysis of structure and material requirement revealed that the volume of M20 cement concrete for RCC structure will be $22.9 \%$ of floor area for laboratory buildings. Vyas and Raisinghani, 2005 [2] determined the optimum spacing of columns and Material consumption in library buildings. They observed that optimum spacing between columns is $5.94 \mathrm{~m}$ centre to centre both ways assuming size of columns as $450 \mathrm{~mm} \times 350 \mathrm{~mm}$. The cost of library module does not vary much for $6.86 \mathrm{~m}$ spacing of column. Clark and Kingston [3] made an observation that High-rise office buildings, which are developed as a response to population growth, rapid urbanization and economic cycles, are indispensable for a metropolitan city development. The political ideology of the city plays an important role in the globalization process (Newman and Tornely [4]; Abu-Ghazalah [5]). The current trend for constructing office buildings is to build higher and higher, and developers tend to compete with one another on heights. The high technology styles have accompanied nearly all new tall buildings and became landmark of many cities internationally (McNeill and Tewdwr-Jones [6]). Nonetheless high-rise office buildings are more expensive to construct per square meter, they produce less usable space and their operation costs are more expensive than conventional office buildings. By the end of 1990s, at more than 30 stories, net to gross floor area ratios of 70-75\% were common in office buildings (Davis Langdon and Everest [7]). However, Yeang [8] stated in his book "The Skyscraper: Bioclimatically Considered" that net-to-gross floor area should not be less than $75 \%$, while $80 \%$ to $85 \%$ is considered appropriate. Watts and et al. [9] compared and revealed the similarities and differences between tallest office buildings at abroad and in Turkey in terms of space efficiency. Although there are no universal formulas for responding to the client's needs or to local influences and constraints such as climate, codes or constructional conditions related to floor slab size and shape, the fundamental design considerations are almost identical almost in office buildings (Kohn and Katz [10]; Strelitz [11]). The space efficiency of a high-rise office building can be achieved by maximizing the Gross Floor Area (GFA) and Net (usable) Floor Area (NFA) as permitted on the local site by the codes and regulations, and in order to enable the developer and owner to get maximum returns from high cost of land, the floors must have sufficient functional space (Kim and Elnimeiri [12]). According to Yeang [13], floor slab efficiency of a typical high-rise office building should generally not be less than $75 \%$, unless the site is too small or too irregular to permit a higher level of space efficiency. Watts et al. [9] state in their recent article, floor slab efficiency is adversely affected by height of a high-rise office building, as the core and structural elements expand relatively to the overall floor slab to satisfy requirements of vertical circulation as well as lateral-load resistance. Square, circular, hexagonal, octagonal and similar plan forms are more space efficient than rectangular plans with high aspect ratios and irregular shapes. Buildings with symmetrical plan shapes are also less susceptible to wind and seismic loads (Arnold [14]; Taranath [15]; Kozak [16]). Leasing depth or lease span is distance of usable area between exterior wall 
and fixed interior element, such as the core or the multi-tenant corridor. In Germany maximum leasing depth is determined by building codes and cannot be more than $8.0 \mathrm{~m}$, whereas in Japan it is typically $18.0 \mathrm{~m}$ (Kohn and Katz [10]). According to Ali and Armstrong [17] the depth of lease span must be between 10.0 and $14.0 \mathrm{~m}$ for office functions, except where very large single tenant groups are to be accommodated. As floors become deeper, the marketability of space decreases significantly (Crone [18]). With reference to floor-to-floor / floor-to-ceiling height, Baum [19] defines quality in office buildings and suggests that the plan layout and the ceiling height are more significant than the following three determinants of building quality: (i) Services and finishes; (ii) external appearance and (iii) durability of materials. Another research project by Ho [20] reveals that functionality of the floor slab is the most important category indicated by all the respondents of the investigation, except for users, who emphasized services as the relative importance of functionality. Commercial functions require a variety of floor-to-ceiling heights ranging between 2.7 and $3.7 \mathrm{~m}$ (Ali and Armstrong [17]), and the depth of the structural floor system varies depending on the floor loads, size of structural bay, and type of floor framing system. Layout of core is critical to the development efficiency and operational effectiveness of a high-rise office building, while also playing a significant role in the way the structure copes with lateral loads (Watts et al [9]). This building type is very attractive to users without cellular offices and has until recently been the standard in Japan and Korea (Kohn and Katz [10]). In United States, steel is commonly used as the structural material and lightweight fire-rated drywall is used to form the walls in order to reduce its thickness and save the foundation cost and construction time (Ho [21]). In 1969 Fazlur Khan [22] classified structural systems for high-rise buildings according to their height. Later, he upgraded these diagrams (Khan [23], [24]), and developed schemes for both steel and concrete (Ali [25]; Ali and Armstrong [17]; Schueller [26]; Iyengar [27]). As per literature review by Ali and Moon [28], structural systems for high-rise buildings are divided into two categories, interior and exterior structures. They are usually arranged as planar assemblies in two principal orthogonal directions and may be employed together as a combined system in which they interact. Another important system in this category is core-supported outrigger structure, which is very widely used for super high-rise buildings (Ali and Moon [28]). The early application of tubular concept is attributed to Fazlur Khan [22] in 1961 (Ali [25]). Widely spaced framed tube, braced tube, tube-in-tube and bundled tube are subcategories of this structural system (Taranath [15]). Other types of exterior structures include space trusses, super frames and exoskeletons (Ali and Moon [28]). These systems are effective in resisting to both lateral and gravity loads, thus enabling maximum space efficiency for office workers, as in the case of Bank of China.

\section{Objective and Scope}

\subsection{Aim and Objective}

If the problem of optimizing the spacing of columns for economical design without compromising on safety and structural stability in a multi-storey building is solved by programming, then impractical values may be obtained like "adopt $25 \mathrm{~mm}$ sq columns at $110 \mathrm{~mm}$ centre to centre. To arrive at a practically executable solution to such optimization problems, it takes a process of permutations and combinations. Main aim of this project is to design an economical G+5 multistoried building for different sizes of slabs and for different plot areas. An attempt is made to determine the optimum spacing of columns in order to keep the cost minimum. Several multistoried buildings with different spacing of columns have been designed using Staad.Pro software and their indirect effect on the cost of the building was studied. A G+5 multistoried building different panel sizes and combinations based on aspect ratios were adopted for design and 
variations on quantities of concrete and steel quantities was observed and compared. Model plans, square and rectangular in shape were developed for different aspect ratios of site area / slab panel for multistoried buildings. Detailed quantities were worked out and relationships were established for cost of cement concrete and steel for a constant floor area of multistoried buildings.

\subsection{Scope}

Without setting some known value, the cases to be studied would be infinite. Some assumptions are inevitable in order to obtain a practicable output. This project was limited for to plot area of $30 \mathrm{~m} \mathrm{X} 30 \mathrm{~m}$ for first case and in second case they were $30 \mathrm{~m} \times 30 \mathrm{~m}$, $30 \mathrm{~m} \mathrm{X} 24 \mathrm{~m}, 30 \mathrm{~m}$ X $18 \mathrm{~m}$ and $30 \mathrm{~m}$ X $12 \mathrm{~m}$. For these plot areas based on aspect ratio, area was divided into panels. It was assumed that quantities of steel and concrete alone effect economy of a building. Cost comparison for steel and concrete quantities as per existing rates (Concrete Rs.5000/per $\mathrm{m}^{3}$ and Steel Rs.50/per $\mathrm{kg}$ ) for different panels for the above mentioned sizes was performed. Based on different panel sizes and plot areas, two cases are considered.

\section{CASE 1}

In this CASE 1, the Plot area size is constant and is equal to $30 \mathrm{~m} \times 30 \mathrm{~m}$ and the Aspect ratio of Panel is varied from 1 to 4 . Aspect ratio of panel size is defined as ratio of longer dimension of the panel to the shorter dimension of the panel.

$\underline{\text { For Panel Aspect ratio }=1}$

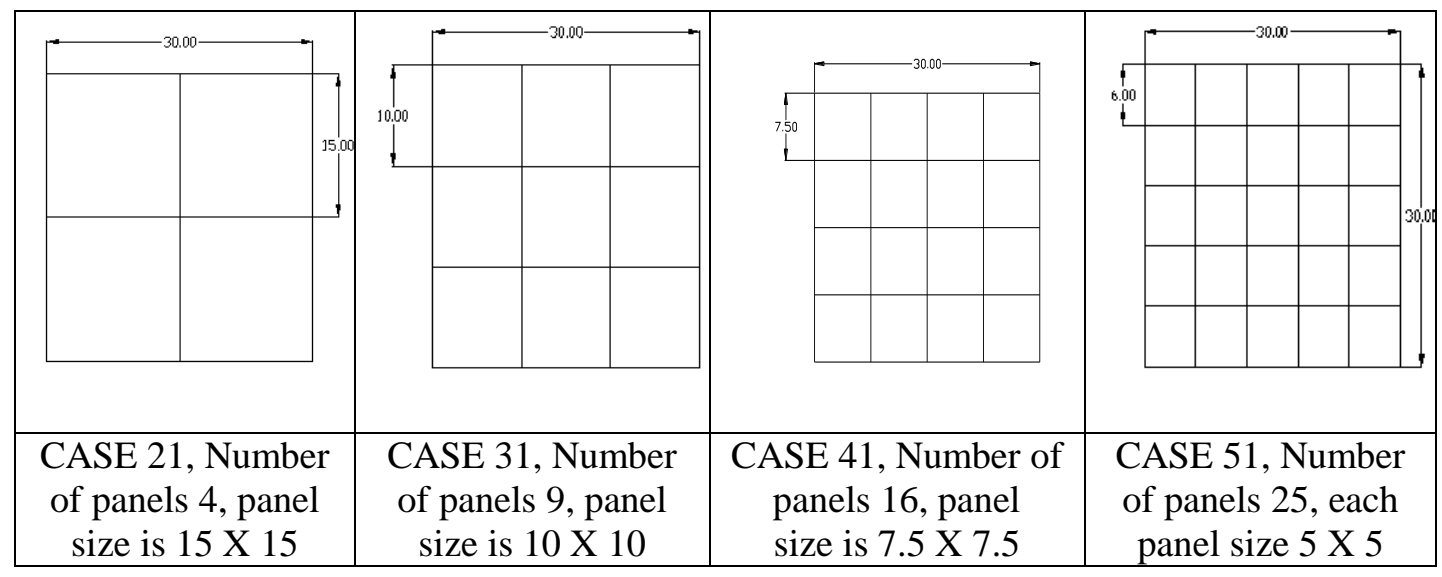

Figure 1. Plot Area of $30 \mathrm{~m} \times 30 \mathrm{~m}$ with Aspect Ratio of Panel as One

For Panel Aspect ratio $=2$

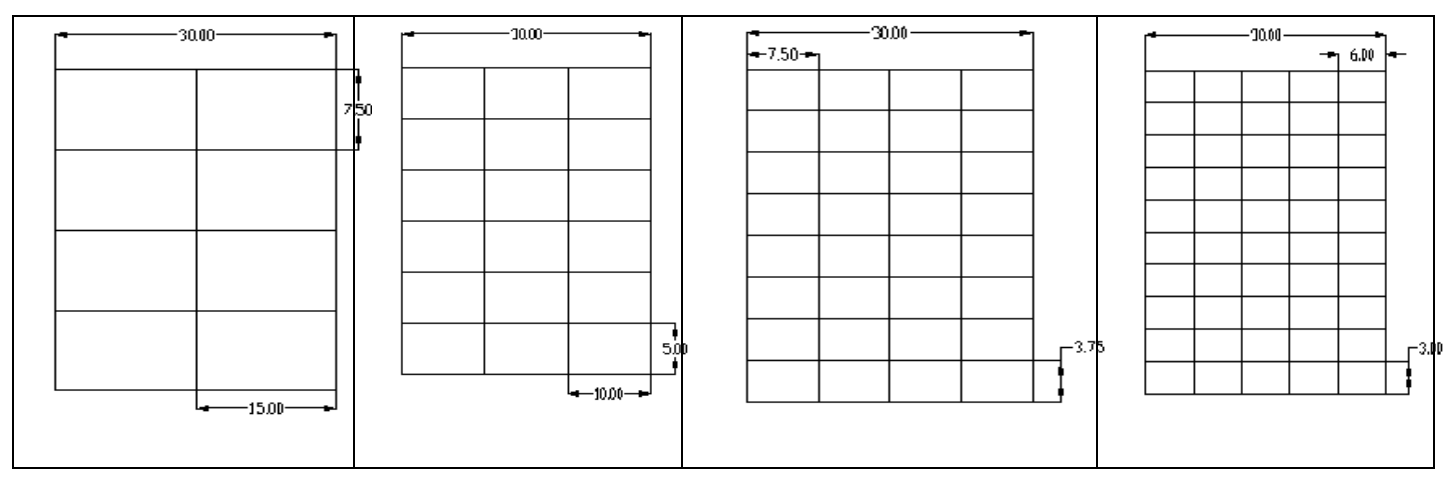




\begin{tabular}{|c|c|c|c|}
\hline $\begin{array}{c}\text { CASE 22, Number } \\
\text { of panels 8, panel } \\
\text { size is 15 X 7.5 }\end{array}$ & $\begin{array}{c}\text { CASE 32, Number } \\
\text { of panels 18, panel } \\
\text { size is 10 X 5 }\end{array}$ & $\begin{array}{c}\text { CASE 42, Number } \\
\text { of panels 32, panel } \\
\text { size is 7.5 X 3.75 }\end{array}$ & $\begin{array}{c}\text { CASE 52, Number } \\
\text { of panels 50, panel } \\
\text { size is 6 X 3 }\end{array}$ \\
\hline
\end{tabular}

Figure 2. Plot Area of $30 \mathrm{~m} \times 30 \mathrm{~m}$ with Aspect Ratio of Panel as Two

For Panel Aspect ratio $=3$

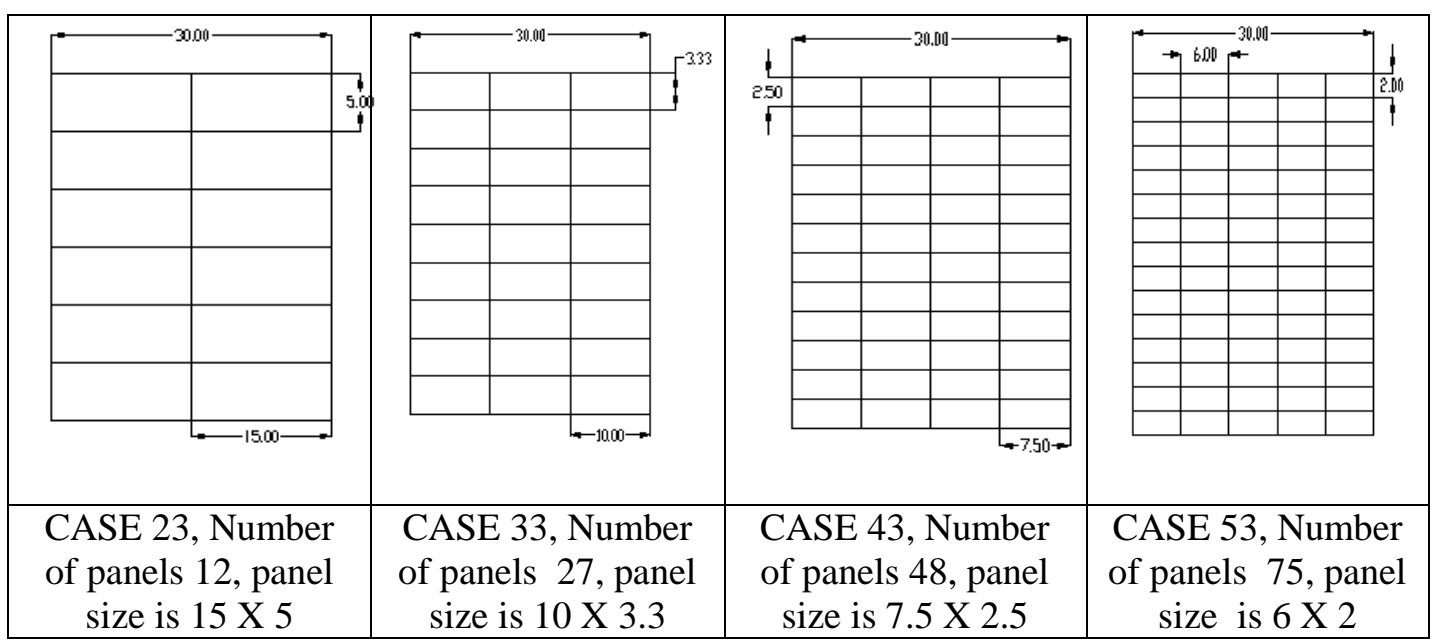

\section{Figure 3. Plot Area of $30 \mathrm{~m} \times 30 \mathrm{~m}$ with Aspect Ratio of Panel as Three}

$\underline{\text { For Panel Aspect ratio }=4}$

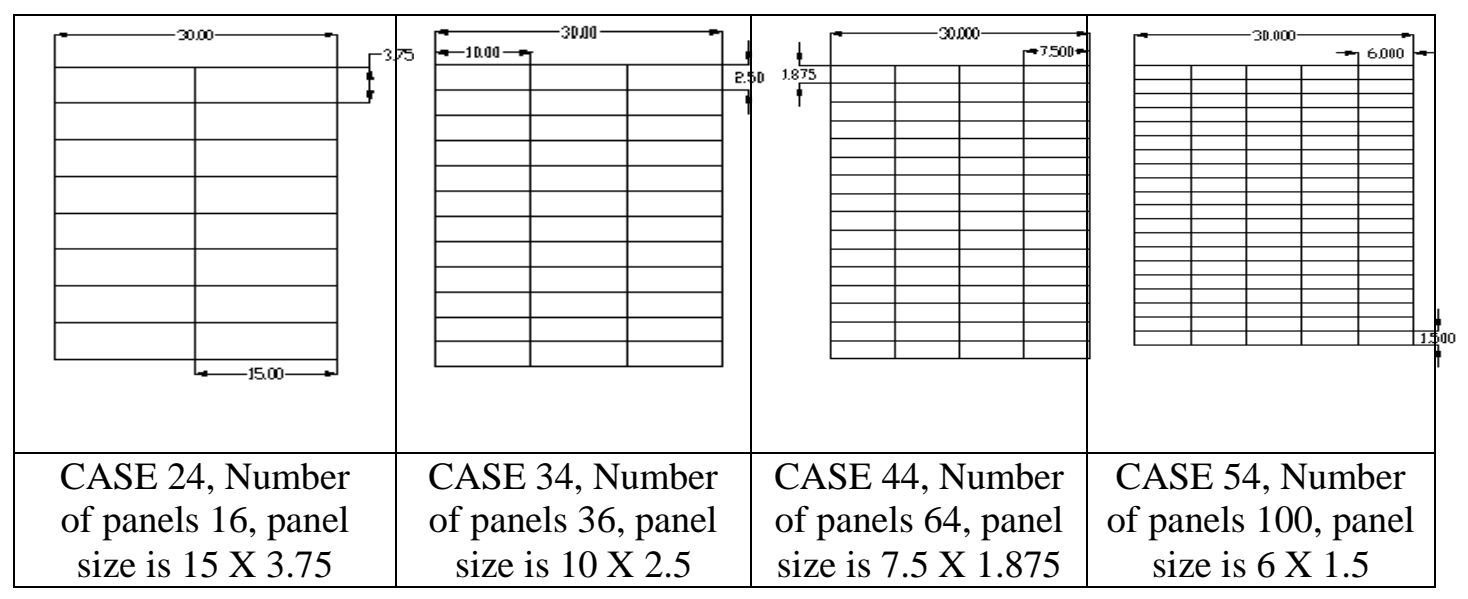

Figure 4. Plot Area of $30 \mathrm{~m} \times 30 \mathrm{~m}$ with Aspect Ratio of Panel as Four

\section{CASE 2}

In this CASE 2, the plot area is not constant. The plot area sizes studied are $30 \mathrm{~m} \mathrm{x}$ $30 \mathrm{~m}, 30 \mathrm{~m} \times 24 \mathrm{~m}, 30 \mathrm{~m} \times 18 \mathrm{~m}$ and $30 \mathrm{~m} \times 12 \mathrm{~m}$. The Aspect ratio's of sites considered are respectively 1, 0.8, 0.6 and 0.4 . Each plot area is again divided into panels of different aspect ratios.

$\underline{\text { Aspect ratio }=1}($ Plot area 30m X 30m) 


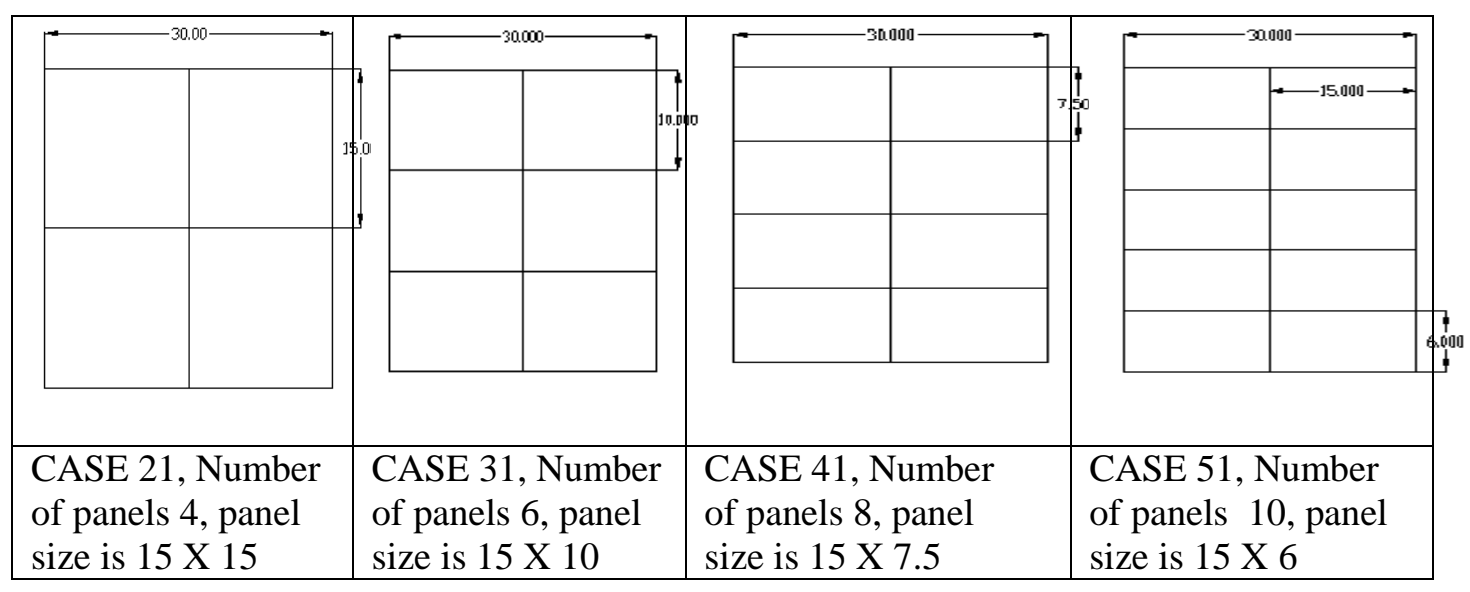

Figure 5. Plot Area of $30 \mathrm{~m} \mathrm{X} \mathrm{30m} \mathrm{with} \mathrm{Aspect} \mathrm{ratio} \mathrm{of} \mathrm{Panel} \mathrm{as} \mathrm{One}$

$\underline{\text { Aspect ratio }-0.8}$ (Plot area $30 \mathrm{~m} \mathrm{X} \mathrm{24m)}$

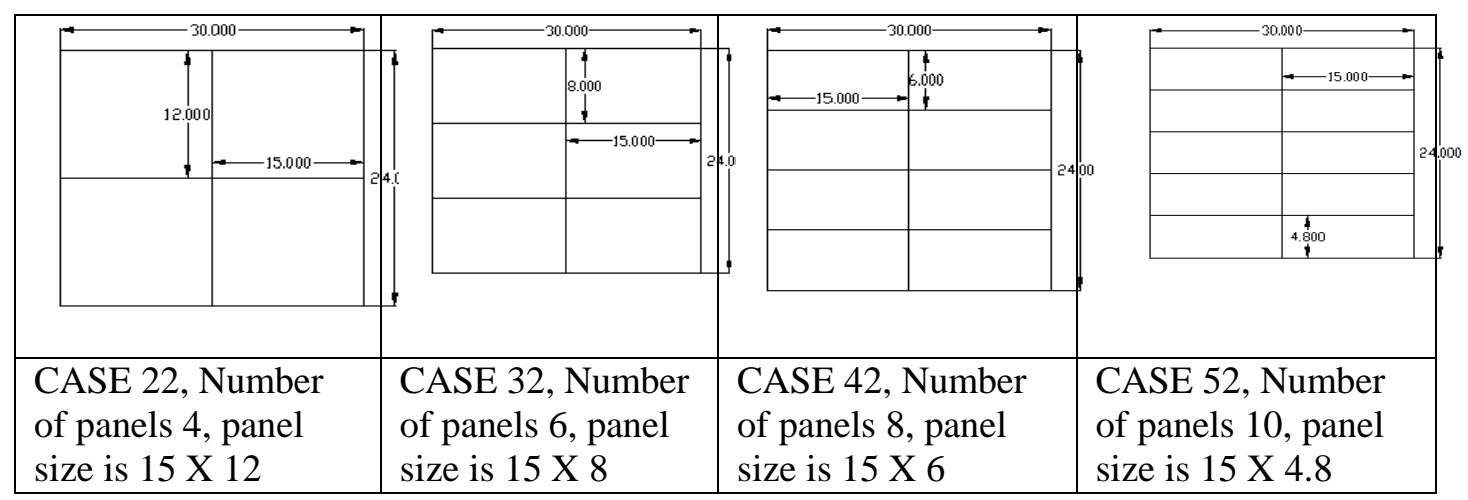

Figure 6. Plot Area of $30 \mathrm{~m} \times 24 \mathrm{~m}$ with Aspect Ratio of Panel as 0.8

Aspect ratio -0.6 (Plot area $30 \mathrm{~m}$ X 18m)

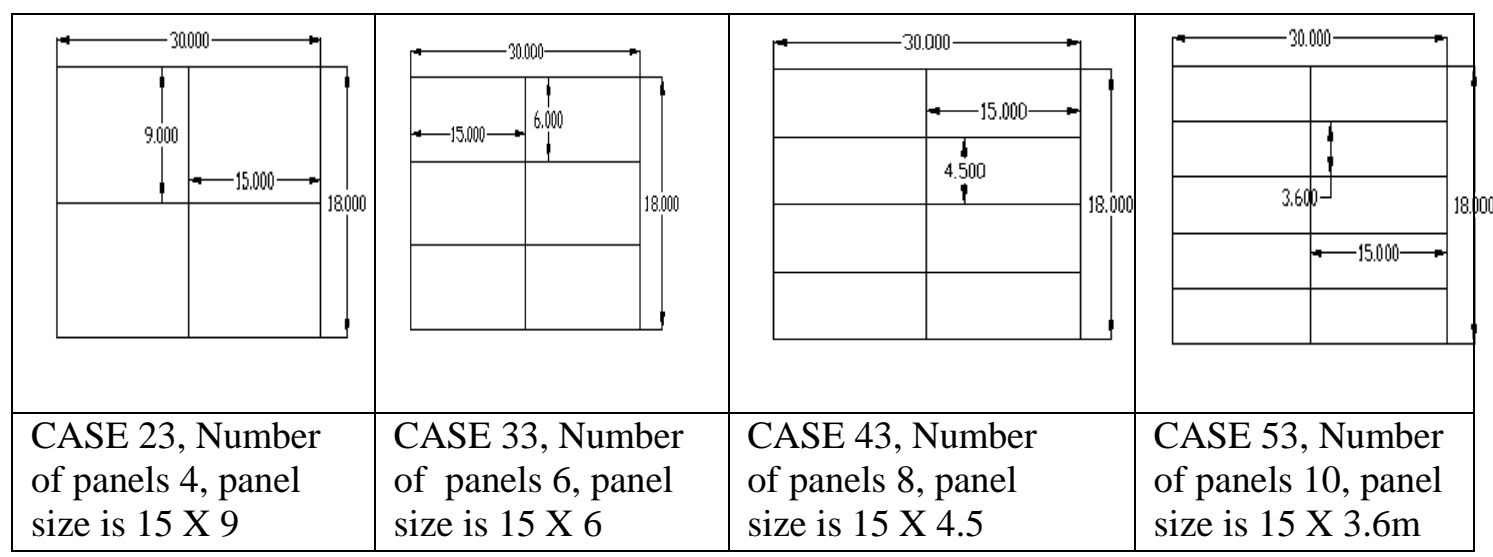

Figure 7. Plot Area of $30 \mathrm{~m} \times 18 \mathrm{~m}$ with Aspect Ratio of Panel as 0.6

Aspect ratio -0.4 (Plot area $30 \mathrm{~m} \mathrm{X} \mathrm{12m)}$ 


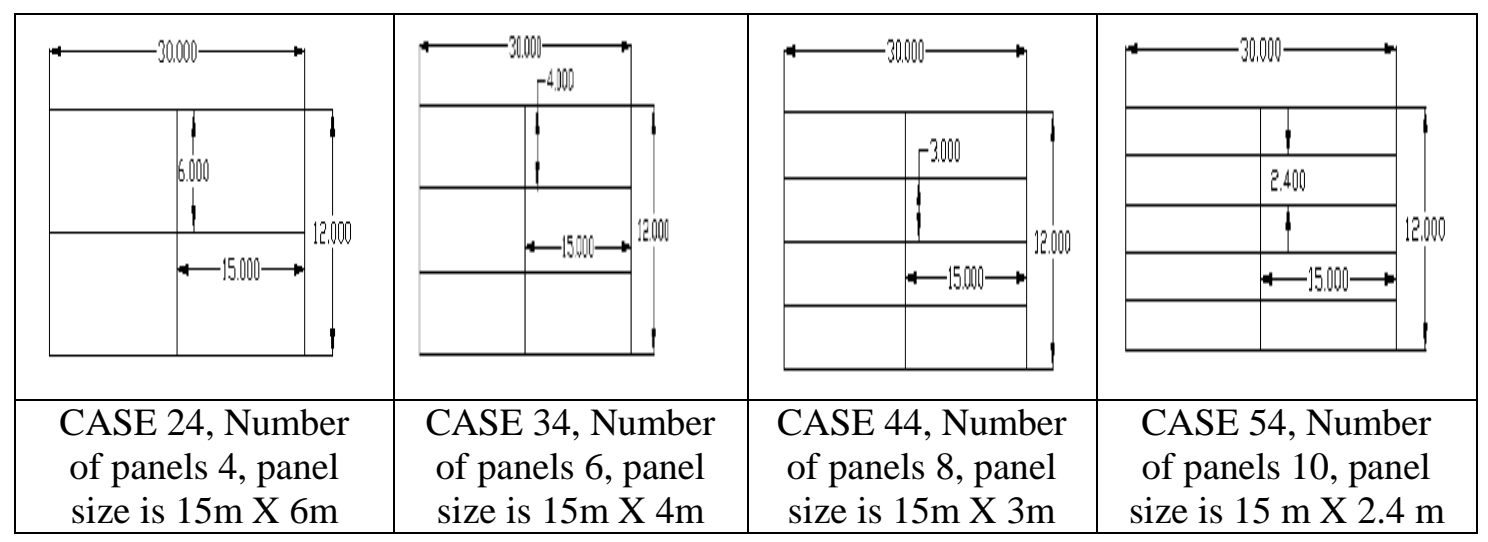

Figure 8. Plot Area of $30 \mathrm{~m} \times 12 \mathrm{~m}$ with Aspect Ratio of Panel as 0.4

\section{Methodology}

\subsection{Method of Analysis}

The entire G+5 structure can be analyzed based on the concept of building frames which consists of multi storied and multi paneled network of beams and columns which are built monolithically and rigidly with each other at their junctions. All the members of such a frame are continuous at their ends. Besides the reduction of moments due to continuity, such structures tend to distribute the loads more uniformly and eliminate the excessive effects of localized loads. The structure can be analyzed as 3 - dimensional structure or it can be broken down into 2 - dimensional plane frames and analyzed. Staad.Pro software was used for the analysis of buildings. The methodology is described in the following flowchart. (See Figure 9)

\subsection{Modeling Structural Framework}

The flow chart shown in Fig. 9 describes the generalized procedure adopted for STAAD.Pro analysis.

\section{Plan with Dimensions}

The plan is generated based upon plotting of the nodes from join 1 to 216. The 3-D model of the proposed structure is shown in Figure 10.

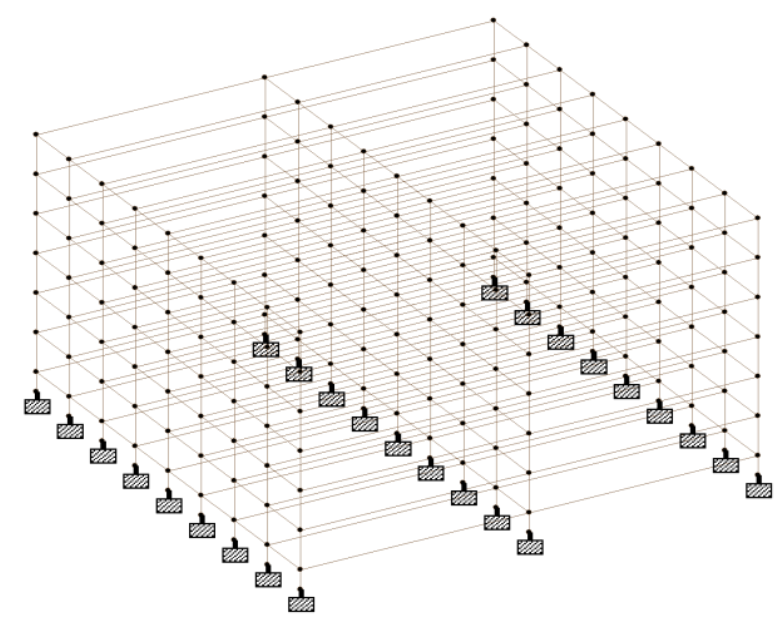

Figure 10. 3D Frame Model of a Multistoried Building 


\subsection{Loads and Load Combinations Considered}

This multistoried building is subjected to self-weight of the slab, beam and columns self-weight, Weights of parapet wall and outer walls in each floor and inner walls in the each floor and also live load on floor. Slab self-weight includes the floor finish. The loads and load combinations considered are as per IS: $875-1987$ [29].

\section{Dead load}

1. Beam and column self-weight

The Multistory building is assigned self-weight of beam and column.

2. Slab self-weight

Assuming $150 \mathrm{~mm}$ thick slab

Total slab self weight including floor finish $=0.15 \times 25+1=4.75 \mathrm{k} \mathrm{N} / \mathrm{m}^{2}$

3. Self weight of parapet wall

Assuming Wall thickness $=230 \mathrm{~mm}$, Wall height $=0.9 \mathrm{~m}$ and Unit weight of brick $=$ $18.85 \mathrm{kN} / \mathrm{m}^{3}$

Total load $=0.23 \times 18.85 \times 0.9=3.9 \mathrm{kN} / \mathrm{m}$

4. Weight of outer walls in the multistoried building

Assuming Outer wall thickness $=0.23 \mathrm{~m}$ and Height of the wall $=3 \mathrm{~m}$

Total weight of outer wall $=0.23 \times 18.85 \times 3=13 \mathrm{kN} / \mathrm{m}$

5. Weight of inner walls in the building

Assuming Inner wall thickness $=0.115 \mathrm{~m}$ and Height of the wall $=3 \mathrm{~m}$,

Total weight of inner wall $=0.115 \times 3 \times 18.85=6.50 \mathrm{k} \mathrm{N} / \mathrm{m}$

6. Live load

Live load was taken as $4 \mathrm{k} \mathrm{N} / \mathrm{m}^{2}$ as it is considered as an office building.

\section{4_Analysis}

The above loads are applied and the structure is modeled, analysed and designed as per IS : 456 - 2000 using Staad.Pro. Then the output file is checked for failed members.

\subsection{Re-Designing}

New properties with increased dimensions are applied to failed members to get the member safe and then the quantities of steel and concrete quantities are obtained. Redesign continues till all the members are safe and then the quantities of steel and concrete for all members are obtained.

\subsection{Steel and Concrete Quantities}

After running the analysis for the input file in Staad.Pro we get the output file. Output file contains the design details of the members of the building and also the quantities of steel and concrete. The steel and concrete quantities are noted and this procedure should be repeated for all cases and the obtained quantities are noted and listed in the below table for further calculations. 


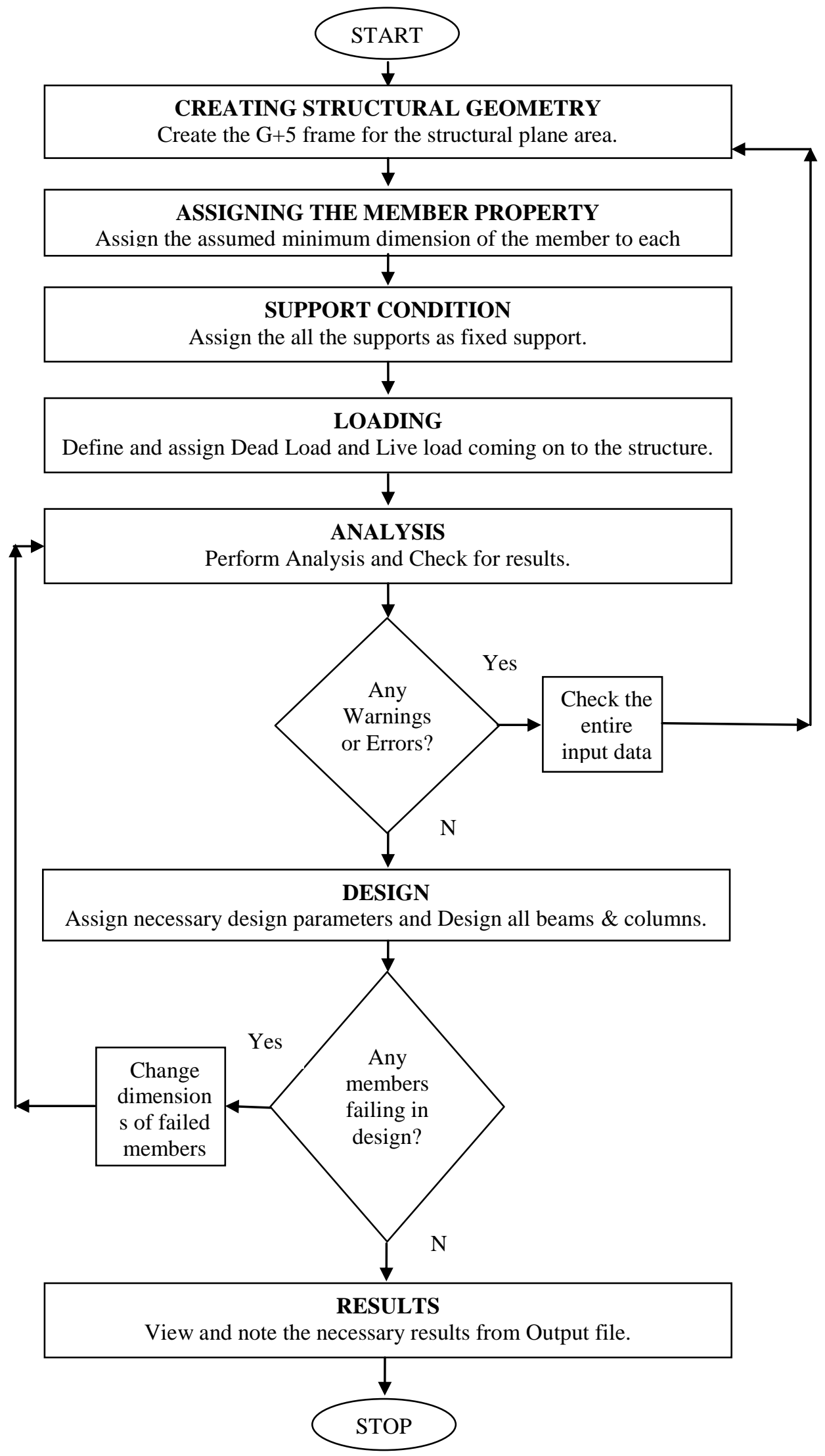

Figure 9. Analysis and Design of Multistoried Buildings Using Staad.Pro 


\section{Observations and Discussions}

\subsection{CASE 1}

For Aspect ratio $=1$ and size of plot $30 \mathrm{~m}$ X $30 \mathrm{~m}$, the concrete quantities are as follows.

Table 1. Concrete Quantity for Different Cases (Plot Size 30m x 30m, Aspect Ratio One)

\begin{tabular}{|l|l|l|l|l|l|l|}
\hline Case & $\begin{array}{l}\text { No of } \\
\text { column }\end{array}$ & $\begin{array}{l}\text { Footings } \\
\text { concrete } \\
\text { quantity in } \\
\text { cu.m }\end{array}$ & $\begin{array}{l}\text { Quantity } \\
\text { of } \\
\text { Beams+ } \\
\text { columns } \\
\text { concrete }\end{array}$ & $\begin{array}{l}\text { Slab } \\
\text { concrete } \\
\text { quantity } \\
\text { (cu.m) }\end{array}$ & $\begin{array}{l}\text { Total } \\
\text { concrete } \\
\text { quantity } \\
\text { (cu.m) }\end{array}$ & $\begin{array}{l}\text { cost of } \\
\text { concrete } \\
5000 /- \\
\text { per cu.m }\end{array}$ \\
\hline 21 & 9 & 48.6 & 271.83 & 810 & 1130.43 & 5652150 \\
\hline 31 & 16 & 86.4 & 202.09 & 810 & 1098.49 & 5492450 \\
\hline 41 & 25 & 135 & 191.22 & 810 & 1136.22 & 5681100 \\
\hline 51 & 36 & 194.4 & 180.35 & 810 & 1184.75 & 5923750 \\
\hline
\end{tabular}

Steel quantities are as follows.

Table 2. Steel Quantity for Different Cases (Plot Size 30m x 30m, Aspect Ratio One)

\begin{tabular}{|l|l|l|l|l|l|}
\hline Case & $\begin{array}{l}\text { No of } \\
\text { columns }\end{array}$ & $\begin{array}{l}\text { Qty of steel } \\
\text { for } \\
\text { beams }+ \\
\text { columns }\end{array}$ & $\begin{array}{l}\text { Qty of steel } \\
\text { slab+ } \\
\text { footings }\end{array}$ & $\begin{array}{l}\text { Total steel } \\
\text { Qty }(\mathrm{kgs})\end{array}$ & $\begin{array}{l}\text { Cost of steel } \\
(50 / \mathrm{kg})\end{array}$ \\
\hline 21 & 9 & 57063.86 & 24423.33 & 81487.19 & 4074359.6 \\
\hline 31 & 16 & 41911.36 & 17938.06 & 59849.42 & 2992471.1 \\
\hline 41 & 25 & 42537 & 18205.84 & 60742.84 & 3037141.8 \\
\hline 51 & 36 & 43163.32 & 18473.9 & 61637.22 & 3081861.05 \\
\hline
\end{tabular}

For aspect ratio $=2$ and size of plot $30 \mathrm{mX} 30 \mathrm{~m}$, the concrete quantities are as follows.

Table 3. Concrete Quantity for Different Cases (Plot Size 30m x 30m, Aspect Ratio Two)

\begin{tabular}{|l|l|l|l|l|l|l|}
\hline Case & $\begin{array}{l}\text { No of } \\
\text { column }\end{array}$ & $\begin{array}{l}\text { Footings } \\
\text { concrete } \\
\text { quantity in } \\
\text { cu.m }\end{array}$ & $\begin{array}{l}\text { Quantity } \\
\text { of Beams } \\
\text { + columns } \\
\text { concrete }\end{array}$ & $\begin{array}{l}\text { Slab } \\
\text { concrete } \\
\text { quantity } \\
\text { (cu.m) }\end{array}$ & $\begin{array}{l}\text { Total } \\
\text { concrete } \\
\text { quantity } \\
\text { (cu.m) }\end{array}$ & $\begin{array}{l}\text { cost of } \\
\text { concrete } \\
5000 /- \\
\text { per cu.m }\end{array}$ \\
\hline 22 & 15 & 81 & 261.1 & 810 & 1152.1 & 5760500 \\
\hline 32 & 28 & 151.2 & 233.81 & 810 & 1195.01 & 5975050 \\
\hline 42 & 45 & 243 & 235.16 & 810 & 1288.16 & 6440800 \\
\hline 52 & 60 & 324 & 259.06 & 810 & 1393.06 & 6965300 \\
\hline
\end{tabular}

Steel quantities are as follows.

Table 4. Steel Quantity for Different Cases (Plot Size 30m x 30m, Aspect Ratio Two)

\begin{tabular}{|l|l|l|l|l|l|}
\hline Case & $\begin{array}{l}\text { No of } \\
\text { columns }\end{array}$ & $\begin{array}{l}\text { Qty of steel } \\
\text { for beams + }\end{array}$ & $\begin{array}{l}\text { Qty of steel } \\
\text { slab+ }\end{array}$ & $\begin{array}{l}\text { Total steel } \\
\text { Qty }(\mathrm{kgs})\end{array}$ & $\begin{array}{l}\text { Cost of steel } \\
(50 / \mathrm{kg})\end{array}$ \\
\hline
\end{tabular}




\begin{tabular}{|l|l|l|l|l|l|}
\hline & & columns & footings & & \\
\hline 22 & 15 & 54380.79 & 23274.98 & 77655.77 & 3882788.41 \\
\hline 32 & 28 & 47246.25 & 20221.4 & 67467.65 & 3373382.25 \\
\hline 42 & 45 & 44185.53 & 18911.41 & 63096.94 & 3154846.84 \\
\hline 52 & 60 & 45121.28 & 19311.91 & 64433.19 & 3221659.39 \\
\hline
\end{tabular}

For aspect ratio $=3$ and size of plot $30 \mathrm{~m}$ X $30 \mathrm{~m}$, the concrete quantities are as follows.

\section{Table 5. Concrete Quantity for Different Cases (Plot Size 30m x 30m, Aspect Ratio Three)}

\begin{tabular}{|l|l|l|l|l|l|l|}
\hline Case & $\begin{array}{l}\text { No of } \\
\text { column }\end{array}$ & $\begin{array}{l}\text { Footings } \\
\text { concrete } \\
\text { quantity in } \\
\text { cu.m }\end{array}$ & $\begin{array}{l}\text { Quantity } \\
\text { of Beams+ } \\
\text { columns } \\
\text { concrete }\end{array}$ & $\begin{array}{l}\text { Slab } \\
\text { concrete } \\
\text { quantity } \\
\text { (cu.m) }\end{array}$ & $\begin{array}{l}\text { Total } \\
\text { concrete } \\
\text { quantity } \\
\text { (cu.m) }\end{array}$ & $\begin{array}{l}\text { cost of } \\
\text { concrete } \\
5000 /- \\
\text { per cu.m }\end{array}$ \\
\hline 23 & 21 & 113.4 & 305.43 & 810 & 1228.83 & 6144150 \\
\hline 33 & 40 & 216 & 272.2 & 810 & 1298.2 & 6491000 \\
\hline 43 & 65 & 351 & 277.18 & 810 & 1438.18 & 7190900 \\
\hline 53 & 96 & 518.4 & 343.43 & 810 & 1671.83 & 8359150 \\
\hline
\end{tabular}

Steel quantities are as follows.

Table 6. Steel Quantity for Different Cases (Plot Size 30m x 30m, Aspect Ratio Three)

\begin{tabular}{|l|l|l|l|l|l|}
\hline Case & $\begin{array}{l}\text { No of } \\
\text { columns }\end{array}$ & $\begin{array}{l}\text { Qty of steel } \\
\text { for beams }+ \\
\text { columns }\end{array}$ & $\begin{array}{l}\text { Qty of steel } \\
\text { slab+ } \\
\text { footings }\end{array}$ & $\begin{array}{l}\text { Total steel } \\
\text { Qty }(\mathrm{kgs})\end{array}$ & $\begin{array}{l}\text { Cost of steel } \\
(50 / \mathrm{kg})\end{array}$ \\
\hline 23 & 21 & 63439.77 & 27152.22 & 90591.99 & 4529599.58 \\
\hline 33 & 40 & 58406.63 & 24998.04 & 83404.67 & 4170233.38 \\
\hline 43 & 65 & 54738.47 & 23428.07 & 78166.54 & 3908326.76 \\
\hline 53 & 96 & 55737.44 & 23855.62 & 79593.06 & 3979653.22 \\
\hline
\end{tabular}

For aspect ratio $=4$ and size of plot $30 \mathrm{~m} \mathrm{X} 30 \mathrm{~m}$, the concrete quantities are as follows.

Table 7. Concrete Quantity for Different Cases (Plot Size 30m x 30m Aspect Ratio Four)

\begin{tabular}{|l|l|l|l|l|l|l|}
\hline Case & $\begin{array}{l}\text { No of } \\
\text { column }\end{array}$ & $\begin{array}{l}\text { Footings } \\
\text { concrete } \\
\text { quantity in } \\
\text { cu.m }\end{array}$ & $\begin{array}{l}\text { Quantity of } \\
\text { Beams+ } \\
\text { columns } \\
\text { concrete }\end{array}$ & $\begin{array}{l}\text { Slab } \\
\text { concrete } \\
\text { quantity } \\
\text { (cu.m) }\end{array}$ & $\begin{array}{l}\text { Total } \\
\text { concrete } \\
\text { quantity } \\
\text { (cu.m) }\end{array}$ & $\begin{array}{l}\text { cost of } \\
\text { concrete } \\
5000 /- \\
\text { per cu.m }\end{array}$ \\
\hline 24 & 27 & 145.8 & 321.32 & 810 & 1277.12 & 6385600 \\
\hline 34 & 52 & 280.8 & 301.4 & 810 & 1392.2 & 6961000 \\
\hline 44 & 85 & 459 & 336.19 & 810 & 1605.19 & 8025950 \\
\hline 54 & 126 & 680.4 & 429.92 & 810 & 1920.32 & 9601600 \\
\hline
\end{tabular}

Steel quantities are as follows.

Table 8. Steel Quantity for Different Cases (Plot Size 30 m x 30 m, Aspect Ratio Four)

\begin{tabular}{|l|l|l|l|l|l|}
\hline Case & $\begin{array}{l}\text { No of } \\
\text { columns }\end{array}$ & $\begin{array}{l}\text { Qty of steel } \\
\text { for beams + }\end{array}$ & $\begin{array}{l}\text { Qty of steel } \\
\text { slab+ }\end{array}$ & $\begin{array}{l}\text { Total steel } \\
\text { Qty }(\mathrm{kgs})\end{array}$ & $\begin{array}{l}\text { Cost of steel } \\
(50 / \mathrm{kg})\end{array}$ \\
\hline
\end{tabular}




\begin{tabular}{|l|l|l|l|l|l|}
\hline & & columns & footings & & \\
\hline 24 & 27 & 77887.34 & 33335.78 & 111223.1 & 5561156.08 \\
\hline 34 & 52 & 71595.86 & 30643.03 & 102238.9 & 5111944.4 \\
\hline 44 & 85 & 69490.98 & 29742.14 & 99233.12 & 4961655.97 \\
\hline 54 & 126 & 63696.11 & 27261.94 & 90958.05 & 4547902.25 \\
\hline
\end{tabular}

\subsection{CASE 2}

For aspect ratio $=1$ and size of plot $30 \mathrm{~m}$ X $30 \mathrm{~m}$, the Concrete quantities are as follows.

\begin{tabular}{|l|l|l|l|l|l|l|}
\hline Case & $\begin{array}{l}\text { No of } \\
\text { column }\end{array}$ & $\begin{array}{l}\text { Footings } \\
\text { concrete } \\
\text { quantity in } \\
\text { cu.m }\end{array}$ & $\begin{array}{l}\text { Quantity } \\
\text { of Beams+ } \\
\text { columns } \\
\text { concrete }\end{array}$ & $\begin{array}{l}\text { Slab } \\
\text { concrete } \\
\text { quantity } \\
\text { (cu.m) }\end{array}$ & $\begin{array}{l}\text { Total } \\
\text { concrete } \\
\text { quantity } \\
\text { (cu.m) }\end{array}$ & $\begin{array}{l}\text { cost of } \\
\text { concrete } \\
5000 /- \\
\text { per cu.m }\end{array}$ \\
\hline 21 & 9 & 48.6 & 288.41 & 810 & 1147.01 & 5735050 \\
\hline 31 & 12 & 64.8 & 250.54 & 810 & 1125.34 & 5626700 \\
\hline 41 & 15 & 81 & 274.74 & 810 & 1165.74 & 5828700 \\
\hline 51 & 18 & 97.2 & 287.4 & 810 & 1194.6 & 5973000 \\
\hline
\end{tabular}

Table 9. Concrete Quantity for Different Cases (Plot Size $30 \mathrm{~m} \times 30 \mathrm{~m}$, Aspect Ratio One)

Steel quantities are as follows.

\begin{tabular}{|l|l|l|l|l|l|}
\hline Case & $\begin{array}{l}\text { No of } \\
\text { columns }\end{array}$ & $\begin{array}{l}\text { Qty of steel } \\
\text { for beams }+ \\
\text { columns }\end{array}$ & $\begin{array}{l}\text { Qty of steel } \\
\text { slab+ } \\
\text { footings }\end{array}$ & $\begin{array}{l}\text { Total steel } \\
\text { Qty }(\mathrm{kgs})\end{array}$ & Cost of steel \\
\hline 21 & 9 & 65739.48 & 28136.5 & 93875.98 & 4693798.87 \\
\hline 31 & 12 & 57677.46 & 24685.95 & 82363.41 & 4118170.64 \\
\hline 41 & 15 & 56750.26 & 24289.11 & 81039.37 & 4051968.56 \\
\hline 51 & 18 & 62921.62 & 26930.45 & 89852.07 & 4492603.67 \\
\hline
\end{tabular}

Table 10. Steel Quantity for Different Cases (Plot Size $30 \mathrm{~m}$ x $30 \mathrm{~m}$, Aspect Ratio One)

For aspect ratio $=0.8$ and size of plot $30 \mathrm{~m} \mathrm{X} 24 \mathrm{~m}$, the concrete quantities are as follows.

Table 11. Concrete Quantity for Different Cases (Plot Size 30 m x 24 m, Aspect Ratio 0.8)

\begin{tabular}{|l|l|l|l|l|l|l|}
\hline Case & $\begin{array}{l}\text { No of } \\
\text { column }\end{array}$ & $\begin{array}{l}\text { Footings } \\
\text { concrete } \\
\text { quantity in } \\
\text { cu.m }\end{array}$ & $\begin{array}{l}\text { Quantity of } \\
\text { Beams }+ \\
\text { columns } \\
\text { concrete }\end{array}$ & $\begin{array}{l}\text { Slab } \\
\text { concrete } \\
\text { quantity ( cu.m) }\end{array}$ & $\begin{array}{l}\text { Total } \\
\text { concrete } \\
\text { quantity } \\
\text { (cu.m) }\end{array}$ & $\begin{array}{l}\text { cost of } \\
\text { concrete } \\
5000 /- \\
\text { per cu.m }\end{array}$ \\
\hline 22 & 9 & 48.6 & 203.5 & 648 & 900.1 & 4500500 \\
\hline 32 & 12 & 64.8 & 225.53 & 648 & 938.33 & 4691650 \\
\hline 42 & 15 & 81 & 234.31 & 648 & 963.31 & 4816550 \\
\hline 52 & 18 & 97.2 & 264.58 & 648 & 1009.78 & 5048900 \\
\hline
\end{tabular}


Steel quantities are as follows

Table 12. Steel Quantity for Different Cases (Plot Size 30m x 24m, Aspect Ratio of $\mathbf{0 . 8}$ )

\begin{tabular}{|l|l|l|l|l|l|}
\hline Case & $\begin{array}{l}\text { No of } \\
\text { columns }\end{array}$ & $\begin{array}{l}\text { Qty of steel } \\
\text { for beams + } \\
\text { columns }\end{array}$ & $\begin{array}{l}\text { Qty of steel } \\
\text { slab+ } \\
\text { footings }\end{array}$ & $\begin{array}{l}\text { Total steel } \\
\text { Qty }(\mathrm{kgs})\end{array}$ & $\begin{array}{l}\text { Cost of steel } \\
(50 / \mathrm{kg})\end{array}$ \\
\hline 22 & 9 & 52184.41 & 22334.93 & 74519.34 & 3725966.87 \\
\hline 32 & 12 & 50961.67 & 21811.59 & 72773.26 & 3638663.24 \\
\hline 42 & 15 & 52045.3 & 22275.39 & 74320.69 & 3716034.42 \\
\hline 52 & 18 & 54065.63 & 23140.09 & 77205.72 & 3860285.98 \\
\hline
\end{tabular}

For aspect ratio $=0.6$ and size of plot $30 \mathrm{mX} 18 \mathrm{~m}$, the concrete quantities are as follows

Table 13. Concrete Quantity for Different Cases (Plot Size $30 \mathrm{~m} \times 18 \mathrm{~m}$, Aspect Ratio 0.6)

\begin{tabular}{|l|l|l|l|l|l|l|}
\hline Case & $\begin{array}{l}\text { No of } \\
\text { column }\end{array}$ & $\begin{array}{l}\text { Footings } \\
\text { concrete } \\
\text { quantity in } \\
\text { cu.m }\end{array}$ & $\begin{array}{l}\text { Quantity } \\
\text { of Beams } \\
\text { + columns } \\
\text { concrete }\end{array}$ & $\begin{array}{l}\text { Slab } \\
\text { concrete } \\
\text { quantity } \\
\text { (cu.m) }\end{array}$ & $\begin{array}{l}\text { Total } \\
\text { concrete } \\
\text { quantity } \\
\text { (cu.m) }\end{array}$ & $\begin{array}{l}\text { cost of } \\
\text { concrete } \\
5000 /- \\
\text { per cu.m }\end{array}$ \\
\hline 23 & 9 & 48.6 & 177.39 & 486 & 711.99 & 3559950 \\
\hline 33 & 12 & 64.8 & 181.13 & 486 & 731.93 & 3659650 \\
\hline 43 & 15 & 81 & 185.3 & 486 & 752.3 & 3761500 \\
\hline 53 & 18 & 97.2 & 205.54 & 486 & 788.74 & 3943700 \\
\hline
\end{tabular}

Steel quantities are as follows.

Table 14. Steel Quantity for Different Cases (Plot Size 30m x 18m, Aspect ratio 0.6 )

\begin{tabular}{|l|l|l|l|l|l|}
\hline Case & $\begin{array}{l}\text { No of } \\
\text { columns }\end{array}$ & $\begin{array}{l}\text { Qty of steel for } \\
\text { beams }+ \\
\text { columns }\end{array}$ & $\begin{array}{l}\text { Qty of steel } \\
\text { slab+ } \\
\text { footings }\end{array}$ & $\begin{array}{l}\text { Total steel } \\
\text { Qty }(\mathrm{kgs})\end{array}$ & $\begin{array}{l}\text { Cost of steel } \\
(50 / \mathrm{kg})\end{array}$ \\
\hline 23 & 9 & 42692.42 & 18272.36 & 60964.78 & 3048238.79 \\
\hline 33 & 12 & 40936.35 & 17520.76 & 58457.11 & 2922855.39 \\
\hline 43 & 15 & 47094.12 & 20156.28 & 67250.4 & 3362520.17 \\
\hline 53 & 18 & 49611.34 & 21233.65 & 70844.99 & 3542249.68 \\
\hline
\end{tabular}

For aspect ratio $=0.4$ and size of plot $30 \mathrm{~m} \mathrm{X} 12 \mathrm{~m}$, the concrete quantities are as follows.

Table 15. Concrete Quantity for Different Cases (Plot Size 30m x 12m Aspect Ratio 0.4)

\begin{tabular}{|l|l|l|l|l|l|l|}
\hline Case & $\begin{array}{l}\text { No of } \\
\text { column }\end{array}$ & $\begin{array}{l}\text { Footings } \\
\text { concrete } \\
\text { quantity in } \\
\text { cu.m }\end{array}$ & $\begin{array}{l}\text { Quantity of } \\
\text { Beams+ } \\
\text { columns } \\
\text { concrete }\end{array}$ & $\begin{array}{l}\text { Slab } \\
\text { concrete } \\
\text { quantity } \\
\text { (cu.m) }\end{array}$ & $\begin{array}{l}\text { Total } \\
\text { concrete } \\
\text { quantity } \\
\text { (cu.m) }\end{array}$ & $\begin{array}{l}\text { Cost of } \\
\text { concrete } \\
5000 /- \\
\text { per cu.m }\end{array}$ \\
\hline 24 & 9 & 48.6 & 130.31 & 324 & 502.91 & 2514550 \\
\hline 34 & 12 & 64.8 & 147.74 & 324 & 536.54 & 2682700 \\
\hline 44 & 15 & 81 & 177.61 & 324 & 582.61 & 2913050 \\
\hline 54 & 18 & 97.2 & 169.82 & 324 & 591.02 & 2955100 \\
\hline
\end{tabular}


Steel quantities are as follows.

Table 16. Steel Quantity for Different Cases (Plot Size 30m x 12m, Aspect Ratio 0.4)

\begin{tabular}{|l|l|l|l|l|l|}
\hline Case & $\begin{array}{l}\text { No of } \\
\text { columns }\end{array}$ & $\begin{array}{l}\text { Qty of steel for } \\
\text { beams + columns }\end{array}$ & $\begin{array}{l}\text { Qty of steel } \\
\text { slab + footings }\end{array}$ & $\begin{array}{l}\text { Total steel } \\
\text { Qty (kgs) }\end{array}$ & $\begin{array}{l}\text { Cost of steel } \\
(50 / \mathrm{kg})\end{array}$ \\
\hline 24 & 9 & 29671.16 & 12699.26 & 42370.42 & 2118520.82 \\
\hline 34 & 12 & 34972.72 & 14968.32 & 49941.04 & 2497052.21 \\
\hline 44 & 15 & 40636.39 & 17392.37 & 58028.76 & 2901438.25 \\
\hline 54 & 18 & 44197.31 & 18916.45 & 63113.76 & 3155687.93 \\
\hline
\end{tabular}

\subsection{Cost Comparison}

Based on observations from Section 5.1 and taking steel and concrete rates as per present rate, costs for two cases and for different plot areas are compared as follows.

Table 17. CASE-1 Cost per Unit Area, Plot Area is $30 \mathrm{~m}$ X 30m (Built-up Area $4500 \mathrm{~m}^{2}$ )

\begin{tabular}{|c|l|l|l|l|l|l|}
\hline $\begin{array}{l}\text { Aspect ratio } \\
\text { of panel }\end{array}$ & Case & $\begin{array}{l}\text { No of } \\
\text { columns }\end{array}$ & $\begin{array}{l}\text { Cost of } \\
\text { concrete }\end{array}$ & $\begin{array}{l}\text { Cost of } \\
\text { steel }\end{array}$ & $\begin{array}{l}\text { Total } \\
\text { cost }\end{array}$ & $\begin{array}{l}\text { Cost per } \\
\text { Unit area }\end{array}$ \\
\hline 1 & 21 & 9 & 5652150 & 4074359.60 & 9726509.60 & 2161.447 \\
\hline & 31 & 16 & 5492450 & 2992471.10 & 8484921.10 & 1885.538 \\
\hline & 41 & 25 & 5681100 & 3037141.80 & 8718241.80 & 1937.387 \\
\hline & 51 & 36 & 5923750 & 3081861.05 & 9005611.05 & 2001.247 \\
\hline 2 & 22 & 15 & 5760500 & 3882788.41 & 9643288.41 & 2142.953 \\
\hline & 32 & 28 & 5975050 & 3373382.25 & 9348432.25 & 2077.429 \\
\hline & 42 & 45 & 6440800 & 3154846.84 & 9595646.84 & 2132.366 \\
\hline & 52 & 60 & 6965300 & 3221659.39 & 10186959.39 & 2263.769 \\
\hline 3 & 23 & 21 & 6144150 & 4529599.58 & 10673749.58 & 2371.944 \\
\hline & 33 & 40 & 6491000 & 4170233.38 & 10661233.38 & 2369.163 \\
\hline & 43 & 65 & 7190900 & 3908326.76 & 11099226.76 & 2466.495 \\
\hline & 53 & 96 & 8359150 & 3979653.22 & 12338803.22 & 2741.956 \\
\hline 4 & 24 & 27 & 6385600 & 5561156.08 & 11946756.08 & 2654.835 \\
\hline & 34 & 52 & 6961000 & 5111944.40 & 12072944.40 & 2682.877 \\
\hline & 44 & 85 & 8025950 & 4961655.97 & 12987605.97 & 2886.135 \\
\hline & 54 & 126 & 9601600 & 4547902.25 & 14149502.25 & 3144.334 \\
\hline
\end{tabular}

For CASE-2

Plot area $30 \mathrm{~m}$ X $30 \mathrm{~m}$ with aspect ratio $=1($ Built-up area is 4500)

Table 18. CASE 2 Cost per Unit Area, Plot Area 30m X 30m with Aspect Ratio of One

\begin{tabular}{|l|l|l|l|l|l|}
\hline Case & $\begin{array}{l}\text { No of } \\
\text { columns }\end{array}$ & $\begin{array}{l}\text { Cost of } \\
\text { concrete }\end{array}$ & $\begin{array}{l}\text { Cost of } \\
\text { steel }\end{array}$ & $\begin{array}{l}\text { Total } \\
\text { Cost }\end{array}$ & $\begin{array}{l}\text { Cost per } \\
\text { unit area }\end{array}$ \\
\hline 9 & 21 & 5735050 & 4693798.87 & 10428848.87 & 2318 \\
\hline 12 & 31 & 5626700 & 4118170.64 & 9744870.64 & 2166 \\
\hline 15 & 41 & 5828700 & 4051968.56 & 9880668.56 & 2196 \\
\hline 18 & 51 & 5973000 & 4492603.67 & 10465603.67 & 2326 \\
\hline
\end{tabular}


Plot area $30 \mathrm{~m}$ X $24 \mathrm{~m}$ with aspect ratio $=0.8$ (Built-up area is 3600)

Table 19. CASE 2 Cost per Unit Area, Plot Area 30m X 24m with Aspect Ratio of 0.8

\begin{tabular}{|l|l|l|l|l|l|}
\hline Case & $\begin{array}{l}\text { No of } \\
\text { columns }\end{array}$ & $\begin{array}{l}\text { Cost } \\
\text { of } \\
\text { concrete }\end{array}$ & $\begin{array}{l}\text { Cost of } \\
\text { Steel }\end{array}$ & $\begin{array}{l}\text { Total } \\
\text { cost }\end{array}$ & $\begin{array}{l}\text { Cost } \\
\text { per unit } \\
\text { area }\end{array}$ \\
\hline 9 & 22 & 4500500 & 3725966.87 & 8226466.87 & 2285 \\
\hline 12 & 32 & 4691650 & 3638663.24 & 8330313.24 & 2314 \\
\hline 15 & 42 & 4816550 & 3716034.42 & 8532584.42 & 2370 \\
\hline 18 & 52 & 5048900 & 3860285.98 & 8909185.98 & 2475 \\
\hline
\end{tabular}

Plot area $30 \mathrm{~m} \mathrm{X} 18 \mathrm{~m}$ with aspect ratio $=0.6$ (Built-up area is 2700)

Table 20 CASE 2 cost per unit area, Plot area is $30 \mathrm{~m} X 18 \mathrm{~m}$ with aspect ratio of 0.6

\begin{tabular}{|l|l|l|l|l|l|}
\hline $\begin{array}{l}\text { No of } \\
\text { column }\end{array}$ & Case & $\begin{array}{l}\text { Cost of } \\
\text { concrete }\end{array}$ & $\begin{array}{l}\text { Cost } \\
\text { of steel }\end{array}$ & Total cost & $\begin{array}{l}\text { Cost per } \\
\text { unit area }\end{array}$ \\
\hline 9 & 23 & 3559950 & 3048238.79 & 6608188.79 & 2447 \\
\hline 12 & 33 & 3659650 & 2922855.39 & 6582505.39 & 2438 \\
\hline 15 & 43 & 3761500 & 3362520.17 & 7124020.17 & 2639 \\
\hline 18 & 53 & 3943700 & 3542249.68 & 7485949.68 & 2773 \\
\hline
\end{tabular}

Plot area $30 \mathrm{~m} \mathrm{X} \mathrm{12m} \mathrm{with} \mathrm{aspect} \mathrm{ratio}=0.4$ (Built-up area is 1800)

Table 20. Cost per Unit Area for CASE-2, (Plot Area 30m X 12m, Aspect Ratio 0.4)

\begin{tabular}{|l|l|l|l|l|l|}
\hline Case & $\begin{array}{l}\text { No of } \\
\text { columns }\end{array}$ & $\begin{array}{l}\text { Cost } \\
\text { of } \\
\text { concrete }\end{array}$ & $\begin{array}{l}\text { Cost of } \\
\text { steel }\end{array}$ & $\begin{array}{l}\text { Total } \\
\text { Cost }\end{array}$ & $\begin{array}{l}\text { Cost } \\
\text { per unit } \\
\text { area }\end{array}$ \\
\hline 9 & 24 & 2514550 & 2118520.82 & 4633070.82 & 2574 \\
\hline 12 & 34 & 2682700 & 2497052.21 & 5179752.21 & 2878 \\
\hline 15 & 44 & 2913050 & 2901438.25 & 5814488.25 & 3230 \\
\hline 18 & 54 & 2955100 & 3155687.93 & 6110787.93 & 3395 \\
\hline
\end{tabular}

\section{Conclusions}

The following general and specific conclusions can be arrived based on the study conducted within the scope of this research work.

1. In Case 1 for aspect ratio $=1$ and for Case 41 with 25 columns, the concrete quantity is observed to be $1136.22 \mathrm{cu} . \mathrm{m}$ and the steel quantity is observed to be $60.74 \mathrm{MT}$. This is the most economical case for $30 \mathrm{~m} \mathrm{X} 30 \mathrm{~m}$ plot area.

2. For plot area of $30 \mathrm{~m} \mathrm{X} 30 \mathrm{~m}$ in Case 2 and for aspect ratio $=1$, Case 31 with 12 columns was observed to be the most economical with 1125.34 cu.m of concrete and 82.36 M.T steel.

3. By comparing the above two results and costs the case- 1 with aspect ratio $=1$ is seems to be economical.

4. In Case 1, Square module $30 \mathrm{~m} \mathrm{X} 30 \mathrm{~m}$ with spacing of columns at $5 \mathrm{~m}$ and 25 panels in both sides was found to be cost effective.

5. In Case- 2 rectangular module $30 \mathrm{~m} \mathrm{X} 24 \mathrm{~m}$ for aspect ratio 0.8 with spacing of columns $15 \mathrm{~m} \mathrm{X} 12 \mathrm{~m}$ and 4 panels in both sides was found to be cost effective. 
6. For rectangular module $30 \mathrm{~m} \mathrm{X} 18 \mathrm{~m}$ for aspect ratio 0.6 with spacing of columns 15 $\mathrm{m} \mathrm{X} 6 \mathrm{~m}$ and 6 panels in both sides was found to be cost effective.

7. For rectangular module $30 \mathrm{~m} \mathrm{X} 12 \mathrm{~m}$ for aspect ratio 0.4 with spacing of columns 15 $\mathrm{m} \mathrm{X} 6 \mathrm{~m}$ and 4 panels in both sides was found to be cost effective.

\section{Acknowledgements}

I thank Mr. Srikanth, my post-graduate student for helping in modeling all the cases in STAAD.Pro,

\section{References}

[1] A. K. Vyas and M. Raisinghani, "Optimum spacing of Columns based upon Cost of Construction in Laboratory Buildings", Journal of Institution of Engineers (India) vol. 88, (2007), pp. 3-8.

[2] A. K. Vyas and M. Raisinghani, "Determination of optimum spacing of columns and Material consumption in library buildings", Journal of Institution of Engineers (India), vol. 86, (2005), pp. 7-17.

[3] W. C. Clark and Kingst, "The skyscraper. A study in the economic height of modern office buildings", American Institute of Steel Construction, New York/Cleveland, (1930).

[4] P. Newman and A. Thornely, "Planning World Cities: Globalization and Urban Politics", Palgrave MacMillan, Basingstoke, (2005).

[5] S. Abu-Ghazalah, "Skyscrapers as Tools of Economic Reform and Elements of Urban Skyline: Case of the Abdali Development Project at Amman", METU Journal of the Faculty of Architecture, vol. 24, no. 1), (2007), pp. 49-70.

[6] D. Mcneill and M. Tewdwr-Jones, "Architecture, Banal Regionalism and Re-territorialism", International Journal of Urban and Regional Research, vol. 27, no. 3, (2003), pp. 738-43.

[7] L. Davisa and Everest, "High-Rise Office Towers - Cost Model", (1997) May, http://www.building.co.uk/story.asp?storyCode=1025316, accessed November 2008).

[8] K. Yeang, "The Skyscraper", Bioclimatically Considered, Academy Editions, London, (1995).

[9] S. Watts, N. Kalita and M. Maclean, "The Economics of Super- Tall Towers", The Structural Design of Tall and Special Buildings, vol. 16, (2007), pp. 457-70.

[10] A. E. Kohn and J. Katz, "Building Type Basics for Office Buildings", S. A. Kliment, ed., John Wiley and Sons, New York, (2002).

[11] Z. Srelitz, "Tall Buildings: A Strategic Design Guide", The British Council for Offices and RIBA Publishing, London, (2005)

[12] H. Kim and M. Elnimeiri, "Space Efficiency in Multi-Use Tall Building", Tall Buildings in Historical Cities - Culture and Technology for Sustainable Cities, October 10-13, Seoul, (2004), pp. 748-55.

[13] K. Yeang, "Service Cores: Detail in Building", John Wiley and Sons, London, (2000).

[14] C. Arnold, "In Earthquakes, Failure Can Follow Form", AIA Journal, (1980) June, pp. 33-41.

[15] B. S. Taranath, "Steel, Concrete and Composite Design of Tall Buildings", McGraw-Hill, Inc., New York, (1998).

[16] J. Kozak, "Steel-Concrete Structures for Multi-storey Buildings", Elsevier, Amsterdam, (1991).

[17] M. M. Ali and P. J. Armstrong, "Architecture of Tall Buildings", Council on Tall Buildings and Urban Habitat Committee 30, McGraw-Hill, Inc., New York, (1995).

[18] G. J. Crone, "The Humanization of Tall Buildings, Council on Tall Buildings and Urban Design", eds. L. S. Beedle, D. B. Rice, Council on Tall Buildings and Urban Habitat, Van Nostrand Reinhold Company, New York; pp. 185-197.

[19] A.E Baum, "Quality and Property Performance", Journal of Property Valuation \& Investment, vol. 12, no. 1, (1994), pp. 31-46.

[20] D. C. W. Ho, "Preferences on Office Quality Attributes", International Real Estate Conference, 26-31 (1999) January, Kuala Lumpur, http:// www.prres.net/papers/Ho_Preferences_On_Office_Quality_ Attributes.pdf, accessed November 2008.

[21] P. H. K Ho, "Economics Planning of Super Tall Buildings in Asia Pacific Cities", Strategic Integration of Surveying Services, FIG Working Week, Hong Kong SAR, China, (2007), May 13-17, pp. 15-30.

[22] F. R. Khan, "Recent structural systems in steel for high-rise buildings", Proceedings of the British Constructional Steelwork Association Conference on Steel in Architecture, British Constructional Steelwork Association, London; pp. 67-78.

[23] F. R. Khan, "Influence of design criteria on selection of structural systems for tall buildings", Proceedings of the Canadian Structural Engineering Conference, Toronto, Canadian Steel Industries Construction Council; (1972), pp. 1-15.

[24] F. R. Khan, "Evolution of structural systems for high-rise buildings in steel and concrete", Tall Buildings in the Middle East and East Europe: Proceedings of the 10th Regional Conference on Tall BuildingsPlanning, Design and Construction, Czechoslovak Scientific and Technical Association, Bratislava; (1973), pp. 75-92. 
[25] M. M. Ali, “Art of the Skyscraper: The Genius of Fazlur Khan”, Rizzoli, New York, (2001).

[26] W. Schueller, "High-rise Building Structure", 2nd Edition, Krieger, Malabar, (1986).

[27] H. Iyengar, "Structural and Steel Systems", Techniques and Aesthetics in the Design of Tall Buildings, Bethlehem, PA, Institute for the Study of High-Rise and Habitat, Lehigh University; (1986), pp. 57-69.

[28] M. M. Ali and K. S. Moon, "Structural Developments in Tall Buildings: Current Trends and Future Prospects", Architectural Science Review, vol. 50, no. 3, (2007), pp. 205-23.

[29] IS: 875-1987. 'Indian Standard Code of Practice for Design Loads (other than Earthquakes) for Buildings and Structures, (2nd revision).' Bureau of Indian Standard, New Delhi.

[30] IS: 456-2000. 'Indian Standard Code of Practice for Design of Reinforced Concrete Structures' Bureau of Indian Standard, New Delhi.

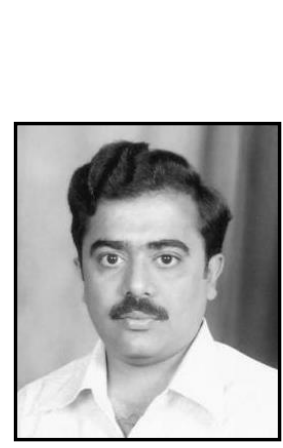

\section{Author}

Markandeya Raju Ponnada, He was born on 25-08-1979 at TUNI of Andhra Pradesh in INDIA. He did his B.Tech in Civil Engineering from Nagarjuna University during 1997-2001 and M.E in Structures from Andhra University during 2001-2003. He was awarded Ph.D by JNTU Hyderabad for his work under the Guidance of Dr.V.Ravindra, Professor of Civil Engineering, JNTU Kakinada in the area of Prestressed steel beams in 2009. He has more than 24 publications in various National and International Journals and Conferences. He has more than 12 years of teaching experience during which he taught subjects like Finite Element Method, Applied Mechanics, Design of Steel Structures, Industrial Structures, Highway Engineering and Prestressed Concrete to Undergraduate and Post graduate Students. $\mathrm{He}$ is presently Working as an Associate Professor and Head of the Department of Civil Engineering, Maharaj Vijayram Gajapathi Raj College of Engineering, Vizianagaram, Andhra Pradesh, INDIA. He has considerable experstise in STAAD.Pro and his areas of interest are Properties of Concrete, Analysis and Design of Pre-stressed Structures and Computer Applications in Structural Engineering. $\mathrm{He}$ has guided more than 23 B.Tech projects, 2 M.Tech dissertations and is presently guiding a one student for his Ph.D. He has vast experience in various consultancy assignments particularly in the area of Multi-storey buildings and Composite bridges. He has authored a book titled "Modified method of Prestressing Steel Trusses by inducing Lack of fit A novel method of Optimizing / Economizing Steel Truss Design" along with Mr.T.Rahuram Sandeep. 